\title{
DROUGHT RESPONSE OF YOUNG PEAR TREES (PYRUS COMMINUS)
}

\author{
KÜÇÜKYUMUK, C. \\ İmir Demokrasi University, Vocational High School, Park and Gardening Plants, Karabağlar, \\ Izmir, Turkey \\ e-mail: cenk.kucukyumuk@idu.edu.tr; phone: +90-533-3474682 \\ (Received $9^{\text {th }}$ Jul 2020; accepted $17^{\text {th }}$ Sep 2020)
}

\begin{abstract}
This experiment was conducted at Fruit Research Institute, MAREM, Eğirdir-Isparta, Turkey to detect the effects of drought stress on young pear trees in 2017. Deveci, Ankara and Margarita pear varieties grafted onto OHxF 333 rootstocks were used. The young pear trees were one year old and they were planted into 18-litre pots with 1:1:0.5 ratio of soil:peat:manure. During the experiment, three different water stress level were applied to all trees $\mathrm{D}_{0}$ : the soil was fully irrigated to reach field capacity in each irrigation, full irrigation, no stress; $\mathrm{D}_{1}: 50 \%$ of $\mathrm{D}_{0}$, moderate stress; $\mathrm{D}_{2}: 25 \%$ of $\mathrm{D}_{0}$, severe stress. Drought stress treatments were applied from July 3 to September 112017 . Photosynthesis $\left(P_{n}\right)$ and stomatal conductance $\left(g_{s w}\right)$ measurements were performed three times after starting drought stress applications. Trunk diameter and leaf area were measured as vegetative development. SPAD measurements were also measured three times during experiment. All pear varieties were affected by drought stress but Deveci variety was determined to be a variety more resistant against to drought stress according to Ankara and Margarita varieties. Ankara and Margarita varieties had similar response to drought stress.
\end{abstract}

Keywords: water stress, gas exchange, stomatal conductance, vegetative parameters

\section{Introduction}

Available water resources not only for agricultural production but also the other sectors have been decreasing day by day. Therefore, we should be more careful when we use water. Because the most using rate of water is used in agricultural production (FAO, 2011), the studies including water stress is getting be more important. Scarcity of water is a severe environmental constraint to plant productivity (Farooq et al., 2009).

Fruits are important for agricultural production and also for human health. Pear is a fruit commonly cultivated after apple. According to the production yield data of 2018, total pear production is 23.852.421 tons and Turkey is at fifth rank with annual pear production of 519.451 tons (FAO, 2020). In recently years, different rootstocks and new varieties have been starting to use in fruit growing. Pear growing has also different rootstocks having different growth vigor. Pear trees need water to grow and development. Therefore, they need to be studied water stress relationships between rootstocks and varieties. OHxF 333 is one of the rootstock used commonly in pear growing (Hepaksoy, 2019). So, we used this rootstock with different varieties in this study.

The one of the most important factors in ensuring the commercial sustainability in pear cultivation is water. In recent days, the countries having threat of drought such as Turkey, studies related with water stress have begun to gain momentum. Not only rootstocks used in fruit growing can affect response of fruit trees to drought stress, but also varieties can affect their responses. Therefore, in addition to rootstocks, researchers should study also relationships between varieties and drought stress. 
The drought resistance of a plant is not only related with the area of root system (rootstock), but also the growth and development rate, the state of the stem and leaf structure, the stomatal conductivity, and the plant's activity status. However, plants cannot overcome drought only by the root development and suction power alterations resulting from the soil moisture conditions. The organs over scion area of plants (trunk, shoot etc.) also play an important role in providing drought resistance (Eriş, 2007).

It is aimed to determine the responses of Deveci, Ankara and Margarita pear varieties grafted onto $\mathrm{OHxF} 333$ rootstock against to different levels of drought stress, in this study.

\section{Materials and methods}

\section{Experimental area and plant material}

The study was carried out in semi-open (non-heated) greenhouse on the experiment field at Fruit Research Institute (Eğirdir, Isparta-Turkey) in 2017. The young pear trees used in the study were one-year-old and Deveci (Pyrus Comminus L. "Deveci"), Ankara (Pyrus Comminus L. "Ankara") and Margarita (Pyrus Comminus L. "Margarita") varieties grafted onto $\mathrm{OHxF} 333$ rootstock were used. The reasons for that they were selected for this study, Ankara and Deveci pear varieties are cultivated as high rate in Turkey (Özaydın and Özçelik, 2014; Sakaldaş and Gündoğdu, 2016). Margarita is a new variety in comparison with Ankara and Deveci. Trees were planted in pots in early April. We selected the pear trees having similar growth vigour before this experiment started. Except from the experiment subjects, five unplanted pots with mixed soil were put into use in order to determine the field capacity. They are placed into a greenhouse with clear plastic cover on the top, sides open in order to prevent the pots to be effected by the rainfall. The temperature and humidity values are recorded with Hobo data logger. Values of relative humidity and temperature of the green house during the study are given in Figure 1. Relative humidity values ranged between $35 \%$ and $78 \%$ but average relative humidity values were about $50 \%$.

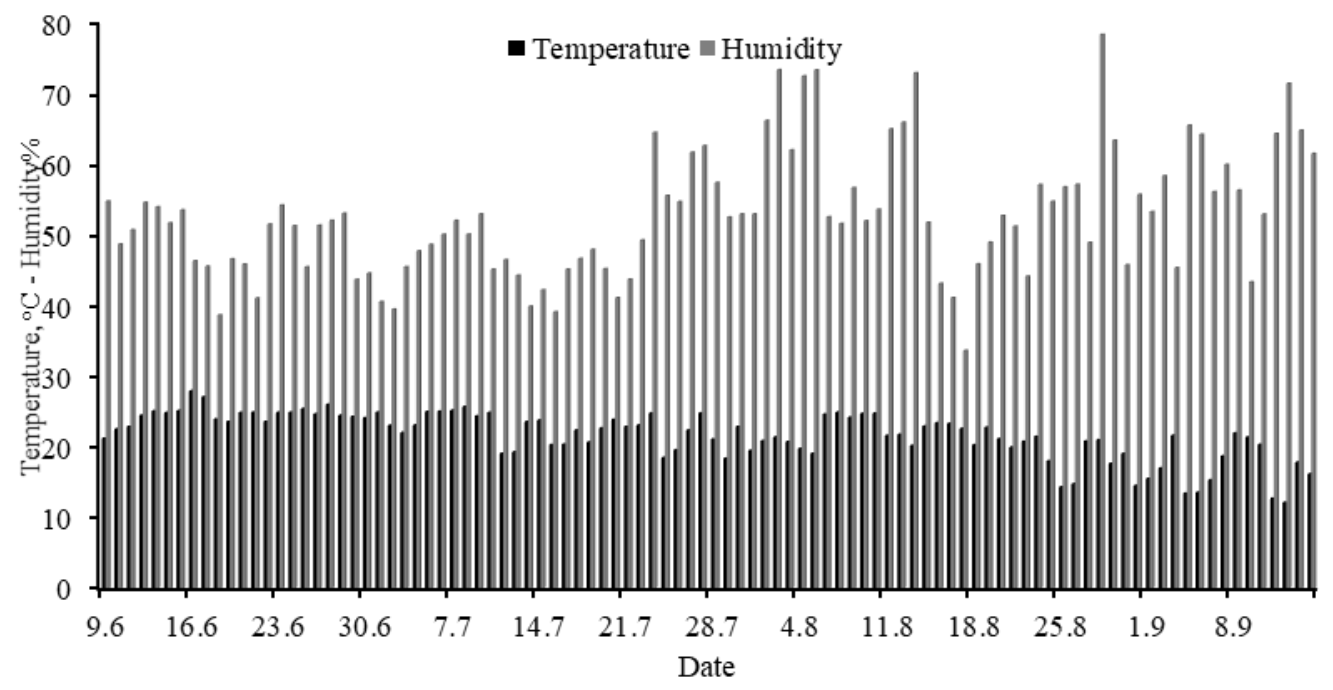

Figure 1. Average daily temperature (black columns) and relative humidity (grey columns) inside of the greenhouse 


\section{The mixed soil in the pots and irrigation water}

The mixed soil (18 liters) of soil:peat:manure (1:1:0.5 ratios) of was placed into 18 liters pots. Irrigation water $\left(\mathrm{EC}=0.3 \mathrm{dS} \mathrm{m}^{-1}\right.$ and $\left.\mathrm{SAR}=1.04\right)$ used for the trees was supplied from a well at Fruit Research Institute. Classification was realized according to the US Salinity Laboratory Graphical System. According to this system, the salinity values of the irrigation water, which are in 250-750 $\mathrm{ECx} 10^{6}$ range, are included in category $\mathrm{C}_{2}$, and in category $\mathrm{S}_{1}$ in terms of SAR value (USSL, 1954). Irrigation water was $\mathrm{C}_{2} \mathrm{~S}_{1}$ class, which is suitable for irrigation.

\section{Irrigation treatments}

Before the study started, the mixed soil in the five pots without plant were saturated with water. Then the pots were covered with aluminum foil to prevent evaporation. After no leaking was observed from the pots, the pot weight was considered as field capacity. Irrigation water was applied to the potted trees every four days as long as the soil water reached to field capacity until July $3^{\text {rd }}$. The water stress treatments started on July $3^{\text {rd }}$ when the temperatures were higher and finished on September 11. Water stress treatments lasted 70 days. There were three different irrigation treatments in the experiment. Treatments were; $\mathrm{D}_{0}$ treatment: available soil water was reached to field capacity for each irrigation, $100 \%$ (control), $\mathrm{D}_{1}$ treatment; irrigated $50 \%$ of water used in $\mathrm{D}_{1}$ treatment $\left(50 \%\right.$ water deficit, moderate stress), $\mathrm{D}_{2}$ treatment; irrigated $25 \%$ of water used in $\mathrm{D}_{1}$ treatment ( $75 \%$ water deficit, severe stress). The field capacity value of the mixed soil in the pots is determined in order to figure out the irrigation water amount used in every irrigation treatment.

Before each treatment, the pots in the $\mathrm{D}_{1}$ treatment were weighed, and the missing water was given to the pots by using a tape (with a 2-litre volume and $50 \mathrm{ml}$ accuracy) to assure that the pots reach the field capacity. To calculate the amount of water used in the other subjects, the average water amount used in the first treatment was taken into consideration. The irrigation water that leaked into the base plate was added back into the pots.

\section{Plant water consumption}

Until programmed irrigations started (July $3^{\text {rd }}$ ), because irrigation water was applied to reach the available water up to field capacity in each irrigation, irrigation water amounts were taken into consideration as plant water consumption. After programmed irrigations started the plant water consumption was calculated for 10-day periods and Equation (1) was used.

$$
\mathrm{ET}_{10 \text { days }}=\mathrm{T}_{1}+\mathrm{I}-\mathrm{T}_{2}
$$

In Equality;

$\mathrm{ET}_{10 \text { days }}=10$-day period plant water consumption $(\mathrm{g})$,

$\mathrm{T}_{1}=$ Previous weight value of pot $(\mathrm{g})$,

$\mathrm{I}=$ The water amounts applied between two weight measurements $(\mathrm{g})$,

$\mathrm{T}_{2}=$ The weight value of pot at the last weighing $(\mathrm{g})$.

The plant water consumption values calculated in weight is converted to volume and expressed as $1 /$ plant. 


\section{Photosynthetic rate (Pn) and stomatal conductance (gsw)}

Plant photosynthetic rate $(\mathrm{Pn})$ and stomatal conductance $\left(\mathrm{g}_{\mathrm{s}}\right)$ were measured by portable Li-Cor 6800 Photosynthesis System (LI-6800XT Portable Photosynthesis System, LI-COR, USA) in three times after starting water stress treatments (July $12^{\text {nd }}$, August $10^{\text {th }}$, September $3^{\text {rd }}$ ). One plant was selected from each replication and totally three different young pear trees were used for each treatment. The leaves were used from the sun-exposed mature leaves of one year old shoots from different sides of the selected trees in each treatment. At least 3 leaves per plant were sampled between 11:00-14:00 on the day before irrigations. The measurement conditions were leaf chamber PAR (photosynthetically active radiation), $1100 \mu \mathrm{mol} \mathrm{m}^{-2} \mathrm{~s}^{-1}$; leaf to air vapor deficit pressure, 1.6-2.7 kPa and chamber $\mathrm{CO}_{2}$ concentration $400 \mu \mathrm{mol} \mathrm{mol}{ }^{-1}$.

\section{SPAD measurement}

The leaf greenness of the young pear trees was determined by a portable chlorophyll meter (SPAD-502; Konica Minolta Sensing, Inc., Japan) in three times after initiation water stress treatments. The results were given as leaf chlorophyll values. SPAD measurements were made on the leaves having similar characteristics (Khan et al., 2003).

\section{Trunk diameter and leaf area}

Trunk diameter were measured in three times after initiation of water stress treatments by using digital caliper. Trunk diameter was measured on east-west and north-south at $15 \mathrm{~cm}$ upper level from grafted point and average of their values was calculated and considered as trunk diameter.

For leaf area measurements, three leaves were picked up from each tree with thirty leaves totally at the end of the water stress treatments (September 3) and the samples were taken from one year old shoot and fully developed leaves. Leaf areas were measured by digital planimeter (Koizumi KP-90 N) as $\mathrm{cm}^{2}$.

\section{Experimental design and statistical analyses}

This study was designed according to Factorial Experimental Design at Randomized Plots with three replications. Each treatment had three replications and there were three plants in each replication. The analysis of variance (ANOVA) test for the data was conducted with JUMP software program and the differences among treatments were compared by means using LSD test.

\section{Results and discussion}

\section{Plant water consumption (ET, evapotranspiration)}

Table 1 shows ET (plant water consumption) values of the teratments. The highest ET was obtained from Deveci variety (46.9 liters) and the others had similar values (42.4 and 42.0 liters). Tree structers and growth vigour may cause these differences (Küçükyumuk et al., 2015a). According to decreasing rates, Ankara and Margarita varieties had higher ET decreasing rates $(35.0 \%$ and $34.8 \%)$ than Deveci variety. Figure 2 presents the 10-day ET graphs. Just after starting drought stress applications $\left(\right.$ July $3^{\text {rd }}$ ) ET values decreased for all varieties. 
Table 1. ET Decreasing rates of treatments

\begin{tabular}{c|c|c|c|c|c|c}
\hline \multirow{2}{*}{$\begin{array}{c}\text { Variety/rootstock } \\
\text { combination }\end{array}$} & \multicolumn{2}{|c|}{ D $_{\mathbf{0}}$} & \multicolumn{2}{|c|}{ D $_{\mathbf{1}}$} & \multicolumn{2}{c}{ D $_{\mathbf{2}}$} \\
\cline { 2 - 7 } & $\begin{array}{c}\text { ET } \\
\text { (l/plant) }\end{array}$ & $\begin{array}{c}\text { Decreasing } \\
\text { rates (\%) }\end{array}$ & $\begin{array}{c}\text { ET } \\
\text { (l/plant) }\end{array}$ & $\begin{array}{c}\text { Decrease } \\
\text { rates (\%) }\end{array}$ & $\begin{array}{c}\text { ET } \\
\text { (1/plant) }\end{array}$ & $\begin{array}{c}\text { Decrease } \\
\text { rates (\%) }\end{array}$ \\
\hline Deveci/OHxF 333 & 46.9 & 0 & 30.5 & 13.2 & 23.2 & 30.9 \\
Ankara/OHxF 333 & 42.4 & 0 & 27.3 & 15.4 & 20.3 & 35.0 \\
Margarita/OHxF 333 & 42.0 & 0 & 26.9 & 17.7 & 21.0 & 34.8 \\
\hline
\end{tabular}
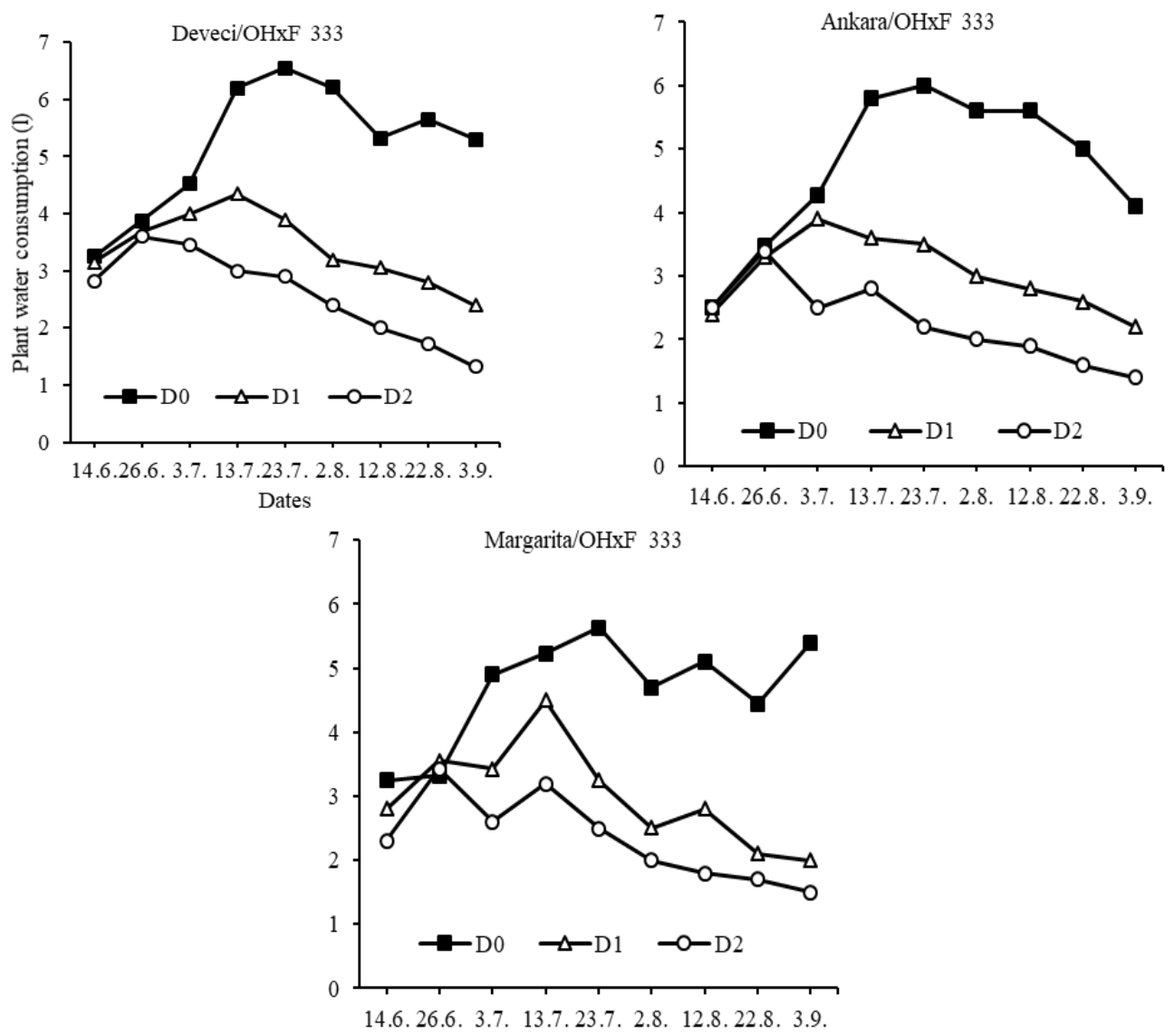

Figure 2. Plant water consumptions of pear trees during growing period

\section{Photosynthetic rate}

The last Pn measurements (September $3^{\text {rd }} 8^{\text {th }}$ ) were made statistical analysis. There were no differences among varieties for trees in no-stress level (vertical column) (Table 2 ). It means that Pn values of different varieties were similar in no-water stress conditions but their responses to drought responses were different. While drought stress (water deficit) was increasing, each variety showed different response. Each drought level had different statistical class. Deveci variety had the highest value in all drought treatments. Margarita variety had the lowest values in drought treatments (4.50 and $1.40 \mu \mathrm{mol} \mathrm{m}^{-2} \mathrm{~s}^{-1}$ in $\mathrm{D}_{1}$ and $\mathrm{D}_{2}$, respectively. Ankara and Margarita were in similar group in $\mathrm{D}_{2}$ treatment. 
Table 2. Photosynthetic rate (Pn) values of drought treatments $\left(\mu \mathrm{mol} \mathrm{m} \mathrm{m}^{-2} \mathrm{~s}^{-1}\right)$

\begin{tabular}{c|c|c|c}
\hline \multirow{2}{*}{ Variety/rootstock combination } & \multicolumn{3}{|c}{ Drought treatments } \\
\cline { 2 - 4 } & $\mathbf{D}_{\mathbf{0}}$ & $\mathbf{D}_{\mathbf{1}}$ & $\mathbf{D}_{\mathbf{2}}$ \\
\hline \multirow{2}{*}{ Deveci/OHF-333 } & $13.86 \mathrm{~A}^{* *} \mathrm{a}^{n s}$ & $7.05 \mathrm{Ba}$ & $3.00 \mathrm{Ca}^{*}$ \\
& $(1.02)^{S D}$ & $(0.31)$ & $(0.17)$ \\
Ankara/OHF-333 & $12.34 \mathrm{~A} * * \mathrm{a}$ & $5.26 \mathrm{Bab}$ & $1.90 \mathrm{Cb}$ \\
& $(0.89)$ & $(0.45)$ & $(0.49)$ \\
Margarita/OHF-333 & $13.45 \mathrm{~A} * * \mathrm{a}$ & $4.50 \mathrm{Bb}$ & $1.40 \mathrm{Cb}$ \\
& $(0.21)$ & $(0.91)$ & $(0.18)$ \\
\hline
\end{tabular}

Capital letters indicate drought stress treatments differences (horizontal); Small letters indicate variety, Differences (vertical). Means followed by the same letter are not significantly different, $* * p<0.01$, ${ }^{*} \mathrm{p}<0.05$, ns: no significance, SD: Standard deviation (in brackets)

Figure 3 shows fluctuations of Pn values after beginning drought stress applications. The Pn values were measured for three times in July $12^{\text {nd }}$, August $10^{\text {th }} 16^{\text {th }}$ and September $3^{\text {rd }} 8^{\text {th }}$. Pn values of no-stress treatments showed fluctuating during growing period but Pn values decreased towards the end of the season in drought stress treatments.
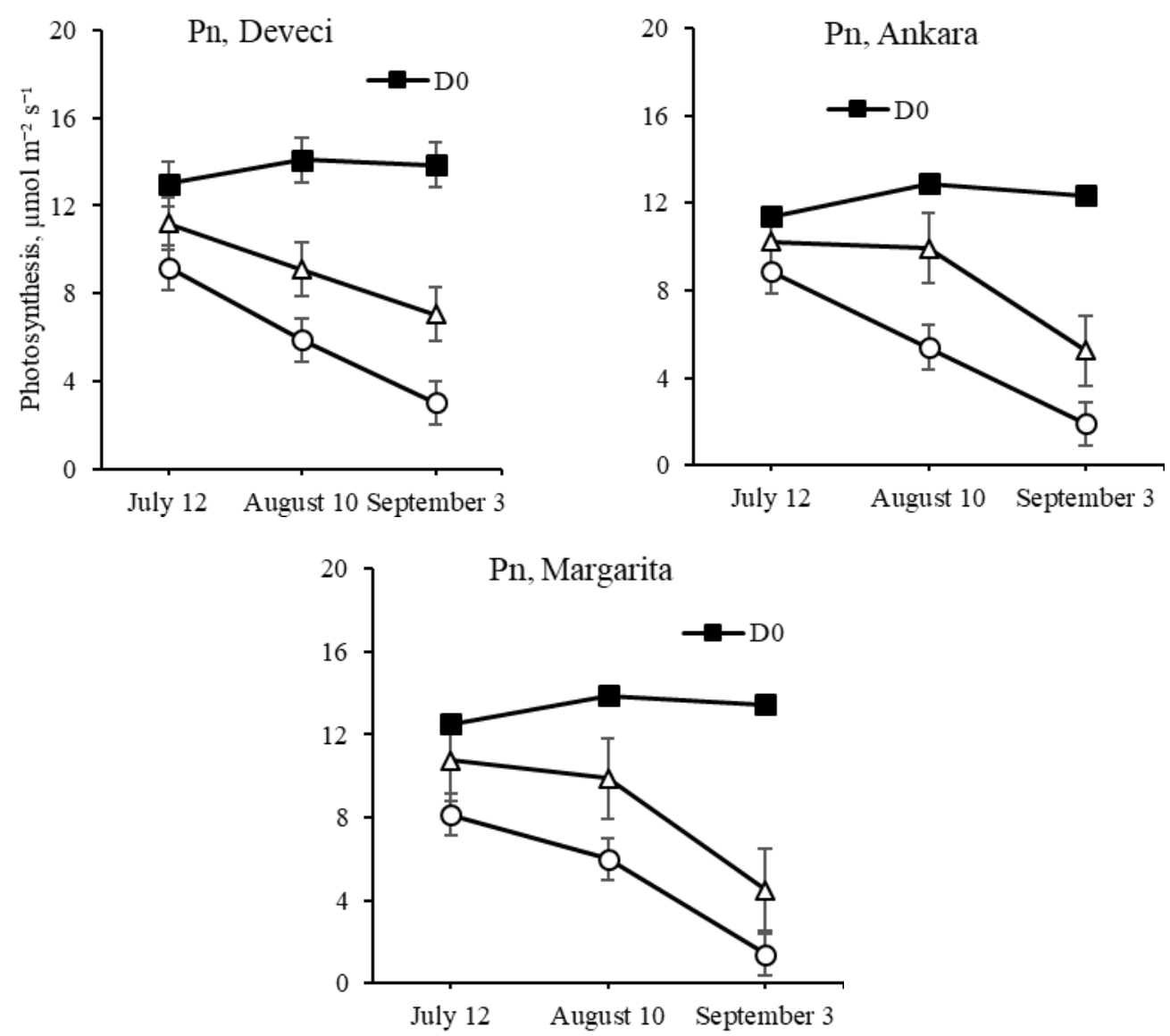

Figure 3. Variation of photosynthetic rate measurements after beginning drought stress applications 
Photosynthetic productivity is an important physiological parameter and it has been widely used to evaluate the plant growth vigor (Kalaji and Pietkiewicz, 2004; Kalaji et al., 2011). The photosynthetic rate (Pn) is one of these parameters (Pérez et al., 1997; Liu et al., 2012). The varieties which belongs to same species can shows different response to drought stress. Zarafshar et al. (2014) stated that drought period decreased Pn values. Tozzi et al. (2018) studied two different pear genotype (PremP009 and Hosui). They found that Pn values were different considered different varieties and PremP009 were higher than Housi.

\section{Stomatal conductance}

The last gsw measurements (September $3^{\text {rd }} 8^{\text {th }}$ ) were made statistical analysis. When drought treatments were considered for each different variety (Table 3, horizontal line), it can be seen each treatment has different statistical group $(\mathrm{p}<0.01)$. It was obtained that the pear varieties used in this study had different responses against different drought levels. It can be said that each different drougth level had different effect on pear trees.

Table 3. Stomatal conductance (gsw) values of drought treatments $\left(\mathrm{mol} \mathrm{m}^{-2} \mathrm{~s}^{-1}\right)$

\begin{tabular}{c|c|c|c}
\hline \multirow{2}{*}{ Variety/rootstock combination } & \multicolumn{3}{|c}{ Drought treatments } \\
\cline { 2 - 4 } & $\mathbf{D}_{\mathbf{0}}$ & $\mathbf{D}_{\mathbf{1}}$ & $\mathbf{D}_{\mathbf{2}}$ \\
\hline \multirow{2}{*}{ Deveci/OHF-333 } & $0.194 \mathrm{~A}^{* *} \mathrm{a}^{n s}$ & $0.106 \mathrm{Ba}^{*}$ & $0.069 \mathrm{Ca}^{*}$ \\
& $(0.012)^{S D}$ & $(0.006)$ & $(0.004)$ \\
Ankara/OHF-333 & $0.186 \mathrm{~A}^{* * \mathrm{a}}$ & $0.076 \mathrm{Bb}$ & $0.052 \mathrm{Cb}$ \\
& $(0.009)$ & $(0.007)$ & $(0.002)$ \\
Margarita/OHF-333 & $0.180 \mathrm{~A}^{* * \mathrm{a}}$ & $0.075 \mathrm{Bb}$ & $0.048 \mathrm{Cb}$ \\
& $(0.008)$ & $(0.006)$ & $(0.004)$ \\
\hline
\end{tabular}

Capital letters indicate drought stress treatments differences; Small letters indicate variety differences, Means followed by the same letter are not significantly different, $* * p<0.01, * \mathrm{p}<0.05$, ns: no significance, SD: Standard deviation (in brackets)

Deveci variety had the highest gsw for all treatments. While Deveci variety is at the first statistical group (0.106 and 0.069 for $\mathrm{D}_{1}$ and $\mathrm{D}_{2}$, respectively) another two varieties were in the similar group. It means that Ankara and Margarita varieties had similar responses according to gsw.

The gsw were measured three times during growing period (Fig. 4). While $\mathrm{D}_{0}$ treatments showed fluctuations, $\mathrm{D}_{1}$ and $\mathrm{D}_{2}$ treatments decreased towards to end of the growing period.

The first adaptation mechanism in plants which are exposed to drought stress is the narrowing or closing of stomata in order to prevent water loss (Osakabe et al., 2014). When the soil moisture decreased in root zone, stomatal conductance decreased because stomas closed and there were limited gas exchange (Kalefetoğlu and Ekmekçi, 2005; Kocaçalışkan, 2005). Some researchers informed increasing stomatal conductance with increasing amount of irrigation water (Pouyafard, 2013; Lepaja et al., 2019). Zarafshar et al. (2014) reported that drought period decreased stomatal conductance. 

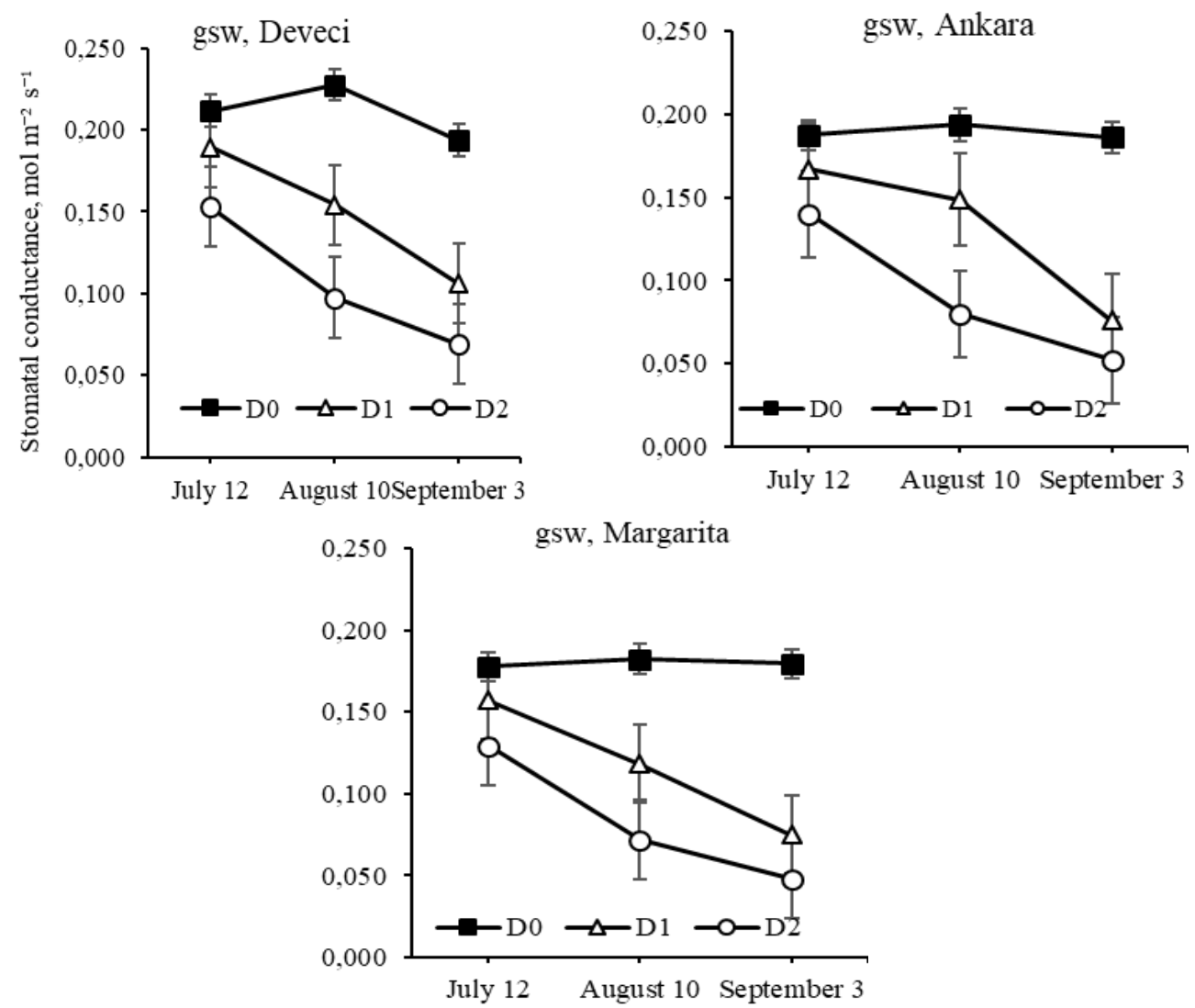

Figure 4. Stomatal conductance ( $g s w)$ measurements after beginning drought stress applications

\section{$S P A D$}

SPAD measurements were significant both for varieties and treatments $(\mathrm{p}<0.01)$ (Table 4). The last SPAD measurements (September $3^{\text {rd }} 8^{\text {th }}$ ) were made statistical analysis. Water deficit was effective for all varieties except $\mathrm{D}_{1}$ treatment $(50 \%$ water deficit) of Deveci variety. The highest value in drought treatments were obtained in $\mathrm{D}_{1}$ treatment of Deveci variety, Margarita had the lowest value (41.2). Figure 5 shows SPAD variation after beginning drought stress applications. SPAD values in all $\mathrm{D}_{0}$ treatments increased during growing period. Only $\mathrm{D}_{1}$ treatment of Deveci variety increased like $\mathrm{D}_{0}$ treatments.

Table 4. SPAD values of drought treatments

\begin{tabular}{c|c|c|c}
\hline \multirow{2}{*}{ Variety/rootstock combination } & \multicolumn{3}{|c}{ Drought treatments } \\
\cline { 2 - 4 } & $\mathbf{D}_{\mathbf{0}}$ & $\mathbf{D}_{\mathbf{1}}$ & $\mathbf{D}_{\mathbf{2}}$ \\
\hline \multirow{2}{*}{ Deveci/OHF-333 } & $65.4 \mathrm{~A}^{* *} \mathrm{a}^{* *}$ & $61.6 \mathrm{Aba} * *$ & $54.0 \mathrm{Ba}^{* *}$ \\
& $(2.6)^{S D}$ & $(2.0)$ & $(9.8)$ \\
Ankara/OHF-333 & $58.0 \mathrm{~A} * * \mathrm{~b}$ & $53.3 \mathrm{ABb}$ & $48.6 \mathrm{Bab}$ \\
& $(3.7)$ & $(4.1)$ & $(2.6)$ \\
Margarita/OHF-333 & $52.6 \mathrm{~A}^{* * \mathrm{c}}$ & $45.6 \mathrm{Bc}$ & $41.2 \mathrm{Cb}$ \\
& $(4.1)$ & $(2.3)$ & $(1.7)$ \\
\hline
\end{tabular}

Capital letters indicate drought stress treatments differences; Small letters indicate variety differences, Means followed by the same letter are not significantly different,

$* * \mathrm{p}<0.01$, SD: Standard deviation (in brackets) 

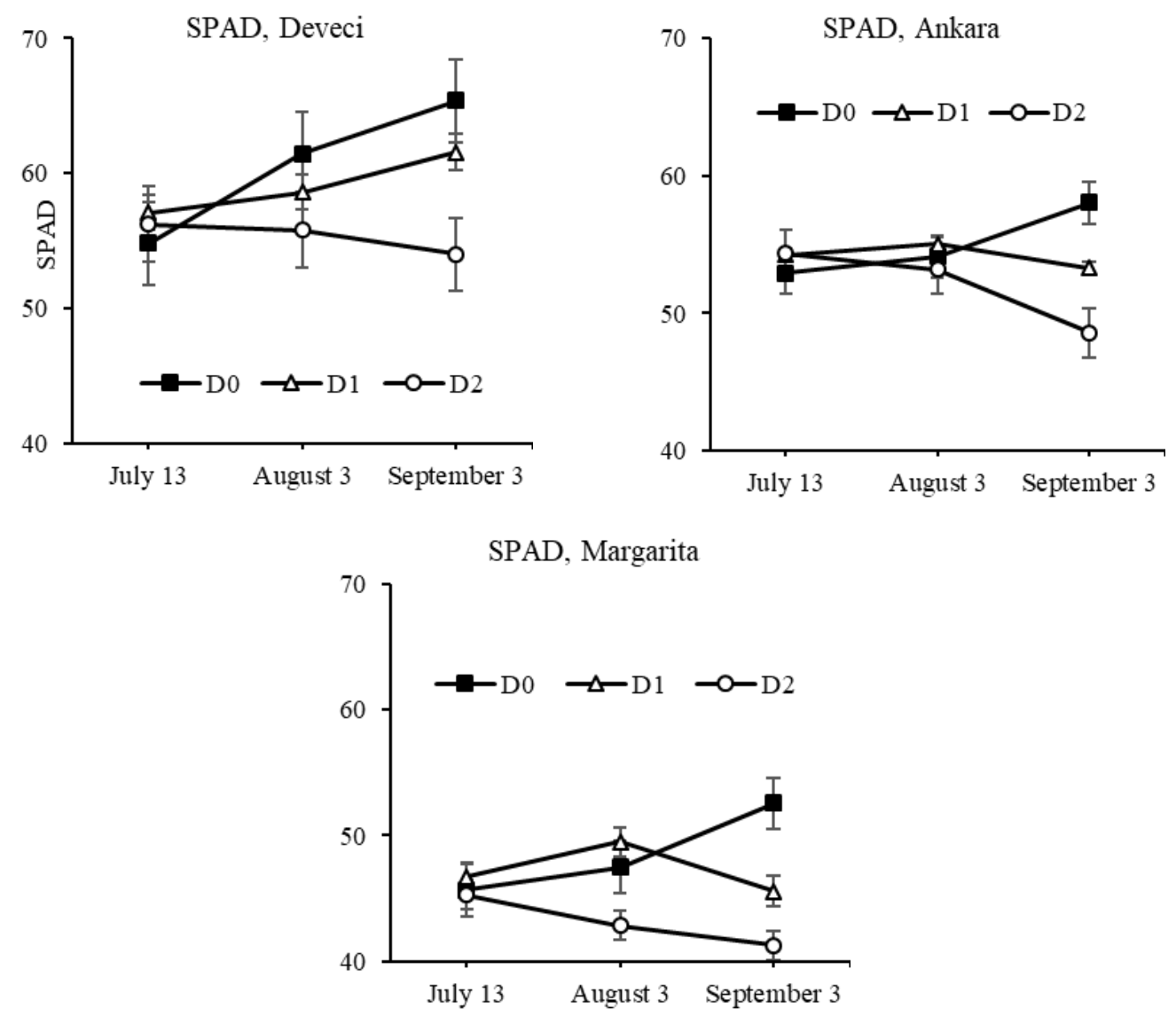

Figure 5. Variation of SPAD values after beginning drought stress applications

Effect of water stress decreases amounts of chlorophyll in plant and leaves and it also prevents chlorophyll occurring (Özer et al., 1997; Kırnak and Demirtaş, 2002; Tatari et al., 2019).

\section{Leaf area}

The leaf areas of all drought treatments were eaffected negatively (Table 5). $\mathrm{D}_{1}$ and $\mathrm{D}_{2}$ drought treatments had similar effects on Ankara and Margarita varieties. Leaf areas decreased between 16.3\%-25.5 (Table 6). The highest decreasing rate was determined in $\mathrm{D} z_{2}$ treatments of Margarita variety with $25.5 \%$. Leaf area development is one of the important indicator of water stress in plants (Küçükyumuk et al., 2015b). Fernandez et al. (1996) stated that water stress causes decreasing leaf area up to 50\% in plants. In order to prevent water loosing from leaves, plants reduce their leaf areas (Kocaçalışkan, 2005). The aim of this is to adapt to drought conditions. Alizadeh et al. (2011) and Kamiloğlu et al. (2014) reported that drought stress had negative effects on leaf areas of fruit trees.

\section{Trunk diameter}

All the results were found to be significant according to statistical analysis $(p<0.05$ and $\mathrm{p}<0.01$ ) in Table 7. Different water deficit rates affected trunk diameter and drought treatments had different effects on trunk diameter values. While $\mathrm{D}_{1}$ treatment in Ankara 
variety didn't effect on trunk diameter, $\mathrm{D}_{1}$ and $\mathrm{D}_{2}$ treatments had similar effects on pear trees in other varieties. As seen in Figure 6, all the trunk diameter values increased except $\mathrm{D}_{2}$ treatment of Ankara variety. Although water deficit affected pear trees, trunk diameter increased except Ankara variety. Increasing rates ranged from $-2.6 \%$ $\left(\mathrm{D}_{2}\right.$-Ankara) to $21.5 \%$ ( $\mathrm{D}_{0}$-Deveci) in Table 8.

Table 5. Leaf area values of the treatments $\left(\mathrm{cm}^{2}\right)$

\begin{tabular}{c|c|c|c}
\hline \multirow{2}{*}{ Variety/rootstock combination } & \multicolumn{3}{|c}{ Drought treatments } \\
\cline { 2 - 4 } & $\mathbf{D}_{\mathbf{0}}$ & $\mathbf{D}_{\mathbf{1}}$ & $\mathbf{D}_{\mathbf{2}}$ \\
\hline \multirow{2}{*}{ Deveci/OHF-333 } & $28.4 \mathrm{~A} * \mathrm{~b}$ & $23.8 \mathrm{ABb}$ & $21.4 \mathrm{Bb}$ \\
& $(3.0)^{S D}$ & $(5.1)$ & $(3.4)$ \\
Ankara/OHF-333 & $27.1 \mathrm{~A} * * \mathrm{~b}$ & $22.0 \mathrm{Bb}$ & $20.7 \mathrm{Bb}$ \\
& $(2.7)$ & $(1.9)$ & $(1.5)$ \\
Margarita/OHF-333 & $36.2 \mathrm{~A} * * \mathrm{a}^{* *}$ & $30.3 \mathrm{Ba} * *$ & $27.0 \mathrm{Ba}^{* *}$ \\
& $(4.9)$ & $(2.4)$ & $(1.4)$ \\
\hline
\end{tabular}

Capital letters indicate drought stress treatments differences; Small letters indicate variety differences, Means followed by the same letter are not significantly different,

$* * \mathrm{p}<0.01, * \mathrm{p}<0.05$, SD: Standard deviation (in brackets)

Table 6. Decreasing rates of leaf areas

\begin{tabular}{c|c|c|c}
\hline Varieties & Treatments & September 3 & Decreasing rates* \\
\hline \multirow{3}{*}{ Deveci } & $\mathrm{D}_{0}$ & 28.38 & 0.0 \\
& $\mathrm{D}_{1}$ & 23.76 & 16.3 \\
& $\mathrm{D}_{2}$ & 21.40 & 24.6 \\
\hline \multirow{4}{*}{ Ankara } & $\mathrm{D}_{0}$ & 27.10 & 0.0 \\
& $\mathrm{D}_{1}$ & 22.02 & 18.7 \\
& $\mathrm{D}_{2}$ & 20.66 & 23.8 \\
\hline \multirow{3}{*}{ Margarita } & $\mathrm{D}_{0}$ & 36.22 & 0.0 \\
& $\mathrm{D}_{1}$ & 30.26 & 16.5 \\
& $\mathrm{D}_{2}$ & 27.00 & 25.5 \\
\hline
\end{tabular}

*Each treatment was compared with $\mathrm{D}_{0}$ treatment for same variety

Table 7. Trunk diameter ( $\mathrm{cm}$ ) of the treatments (at the end of the study, September $11^{\text {th }}$ )

\begin{tabular}{c|c|c|c}
\hline \multirow{2}{*}{ Variety/rootstock combination } & \multicolumn{3}{|c}{ Drought treatments } \\
\cline { 2 - 4 } & $\mathbf{D}_{\mathbf{0}}$ & $\mathbf{D}_{\mathbf{1}}$ & $\mathbf{D}_{\mathbf{2}}$ \\
\hline \multirow{2}{*}{ Deveci/OHF-333 } & $13.7 \mathrm{~A} * \mathrm{~b}$ & $11.7 \mathrm{Bb}$ & $11.1 \mathrm{Bb}$ \\
& $(0.5)^{S D}$ & $(2.9)$ & $(1.0)$ \\
Ankara/OHF-333 & $16.8 \mathrm{~A}^{* a}$ & $16.0 \mathrm{Aba} * *$ & $15.0 \mathrm{Ba}$ \\
& $(1.4)$ & $(1.1)$ & $(0.9$ \\
Margarita/OHF-333 & $16.8 \mathrm{~A} * \mathrm{a}^{* *}$ & $15.7 \mathrm{Ba}$ & $15.5 \mathrm{Ba}^{* *}$ \\
& $(1.3)$ & $(0.8)$ & $(1.1)$ \\
\hline
\end{tabular}

Capital letters indicate drought stress treatments differences; Small letters indicate variety differences, Means followed by the same letter are not significantly different,

$* * \mathrm{p}<0.01, * \mathrm{p}<0.05$, SD: Standard deviation (in brackets) 

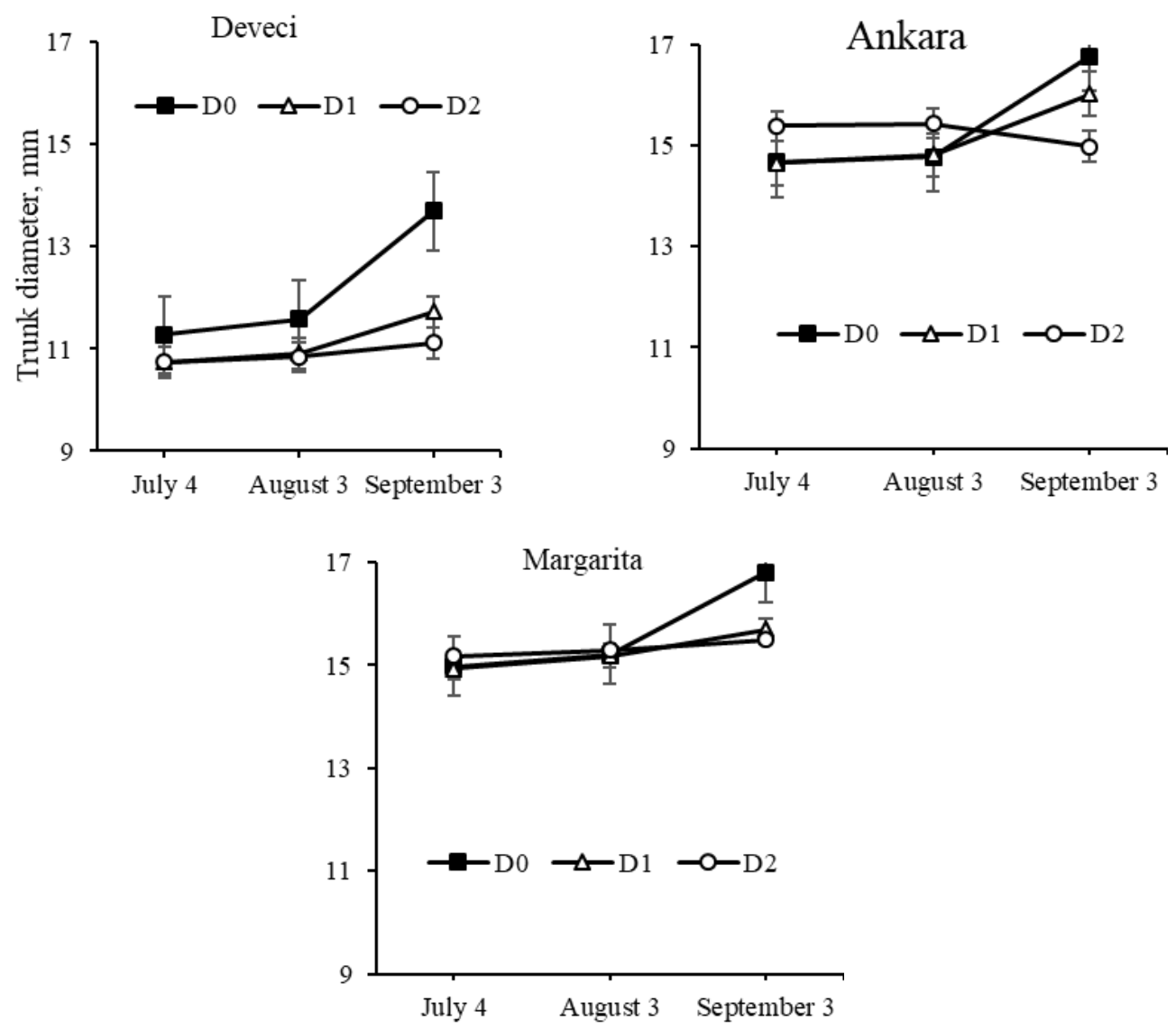

Figure 6. Variation of trunk diameter values during growing period

Table 8. Increasing rates of trunk diameter values

\begin{tabular}{c|c|c|c|c}
\hline Varieties & Treatments & July 4 & September 11 & Increasing rates \\
\hline \multirow{3}{*}{ Deveci } & D0 & 11.28 & 13.69 & 21.5 \\
& D1 & 10.75 & 11.73 & 9.1 \\
& D2 & 10.75 & 11.12 & 3.4 \\
\hline \multirow{4}{*}{ Ankara } & D0 & 14.67 & 16.77 & 14.3 \\
& D1 & 14.66 & 16.03 & 9.4 \\
& D2 & 15.39 & 14.99 & -2.6 \\
\hline \multirow{3}{*}{ Margarita } & D0 & 14.98 & 16.81 & 12.2 \\
& D1 & 14.94 & 15.69 & 5.1 \\
& D2 & 15.18 & 15.50 & 2.2 \\
\hline
\end{tabular}

Kaya (2012) reported that there was a linear relationship between amounts of irrigation water and trunk diameter in young olive trees. Water deficit applications decrease trunk diameter development (Alizadeh et al., 2011; Parlak, 2014). 


\section{Conclusions}

Different pear varieties grafted onto same rootstock (OHxF 333) had different responses against water deficit. According to plant water content indicators such as $\mathrm{Pn}$ and stomatal conductance values, it was determined that Deveci/OHxF 333 pear trees were less affected by water stress. When the other parameters were also considered like SPAD and trunk diameter measurements, Deveci variety was less affected.

When all results were evaluated together, the most resistance one was determined as Deveci/OHxF 333 and it was followed by Ankara/OHxF 333 and Margarita/OHxF 333.

This study was conducted young pear trees. I highly recommend that studies having similar drought levels should be conducted on pear trees in yield age.

\section{REFERENCES}

[1] Alizadeh, A., Alizade, V., Nassery, L., Eivazi, A. (2011): Effect of drought stress on apple dwarf rootstocks. - Technical Journal of Engineering and Applied Sciences 1(3): 86-94.

[2] Eriş, A. (2007): Physiology of horticultural crops. - Uludağ University Agriculture Faculty Lecture Notes 11, 152p. Bursa.

[3] FAO (2011): The state of the world's land and water resources for food and agriculture (SOLAW): managing systems at risk. - Food and Agriculture Organization of the United Nations, Rome and Earthscan, London. (also available at: http://www.fao.org/docrep/017/i1688e/i1688e.pdf).

[4] FAO (2020): http://www.fao.org/faostat/en/\#data/QC. - Food and Agricultural Organization of the United Nations, Date of access: 08.05.2020.

[5] Farooq, M., Wahid, A., Kobayashi, N., Fujita, D., Basra, M. A. (2009): Plant drought stress: effects, mechanisms and management. - Agronomy for Sustainable Development 29: 185-212. DOI: 10.1051/agro:2008021.

[6] Fernandez, C. J., Mcinnes, K. J., Cothren, J. T. (1996): Water status and leaf area production in water and nitrogen stressed cotton. - Crop Science 36: 1224-1233.

[7] Hepaksoy, S. (2019): Rootstock using in Fruit Growing: Pear Rootstocks. - Turkish Journal of Scientific Reviews 12(2): 69-74. E-ISSN: 2146-0132.

[8] Kalaji, M. H., Pietkiewicz, S. (2004): Some physiological indices to be exploited as a crucial tool in plant breeding. - Plant Breeding and Seeds Science 49: 19-39.

[9] Kalaji, M. H., Bosa, K., Kościelniak, J., Hossain, Z. (2011): Chlorophyll a fluorescence a useful tool for the early detection of temperature stress in spring barley (Hordeum vulgare L.). - OMICS 15(12): 925-934.

[10] Kalefetoğlu, T., Ekmekçi, Y. (2005): Effects of drought stress and resistance mechanism on plants. - Gazi University Journal of Natural Science 18(4): 723-740.

[11] Kamiloğlu, Ö., Sivritepe, N., Önder, S., Dağhan, H. (2014): Effects on water stress on plant growth and physiological characteristics of some grape varieties. - Fresenius Environmental Bulletin 23(9): 2155-2163.

[12] Kaya, Ü. (2012): The effects of different irrigation levels on some vegetative parameters in nurseries of Ayvalık and Gemlik olive varieties (Ayvalık ve Gemlik zeytin fidanlarinda farkli sulama düzeylerinin bazi büyüme parametreleri üzerine etkisi). - Olive Science 3(1): 35-42.

[13] Khan, W., Prithiviraj, B., Smith, D. L. (2003): Photosynthetic responses of corn and soybean to foliar application of salicylates. - Journal of Plant Physiology 160(5): 485492. 
[14] Kırnak, H., Demirtaş, M. N. (2002): Determining of physiological and morphological variations on sweet cherry nurseries under water stress. - Atatürk University Journal of Agricultural Faculty 33(3): 265-270.

[15] Kocaçalışkan, İ. (2005): Plant Phsiology. $-5^{\text {th }}$ Edition, Dumlupınar University, KütahyaTurkey, 318p.

[16] Küçükyumuk, C., Yıldız, H., Sarısu, H. C., Kaçal, E., Koçal, H. (2015a): Response of sweet cherry grafted on different rootstocks to water stress. - Fresenius Environmental Bulletin 24(9a): 3014-3024.

[17] Küçükyumuk, C., Sarısu, H. C., Yıldız, H., Kaçal, E., Koçal, H. (2015b): Effect of water stress on the some vegetatif growth parameters of cultivar grafted on different rootstocks 0900 ziraat sweet cherry. - Yüzüncü Y1l University Journal of Agricultural Science 25(2): 180-192.

[18] Lepaja, L., Kullaj, K., Lepaja, K., Avdiu, V., Zajmi, A. (2019): Effect of water stress on some physiological indices in young pear trees. - ActaHorticulture XXX IHC Proceeding International Symposium on Water and Nutrient Relations and Management of Horticulture Crops. DOI 10.17660/ActaHortic.2019.1253.10.

[19] Liu, B. H., Cheng, L., Liang, D., Zou, Y. J., Ma, F. W. (2012): Growth, gas exchange, water use efficiency, and carbon isotope composition of 'Gala Gala' apple trees grafted onto 9 Chinese rootstocks in response to drought stress. - Photosynthetica 50(3): 401410.

[20] Osakabe, Y., Osakabe, K., Shinozaki, K., Tran, L. P. (2014): Response of plants to water stress. - Front Plant Science 5: 86.

[21] Özaydın, A. G., Özçelik, S. (2014): Effect of Oven Drying on Some Physiochemical Properties of Ankara Pear. - Academic Food Journal 12(4): 17-26.

[22] Özer, H., Karadoğan, T., Oral, E. (1997): Water stress and resistance mechanism in plants. - Journal of the Faculty of Agriculture 28(3): 488-495.

[23] Parlak, M. (2014): Change of crop water stress index (CWSI) depending on water stress on ayvalik young olive tree and determination of relationship between cwsi and stomatal conductance. - Ege University Applied Science Institute MSc, 63p., İzmir-Türkiye.

[24] Pérez, C., Val, J., Monge, E. (1997): Photosynthetic changes of "Prunus aviuml." grafted on different rootstocks in relation to mineral deficiencies. - Acta Horticulturae 448: 8185 .

[25] Pouyafard, N. (2013): Determination of some physiologic and morphologic changes of young olive ( $\mathrm{Cv}$ Ayvalık) tree under water stress in coastal Ege. - Ege University Natural Science Institute MSc, 92p., İzmir-Turkey.

[26] Sakaldaş, M., Gündoğdu, M. A. (2016): The Effects of Preharvest 1- Methylcyclopropene (Harvista) Applications on Fruit Drop and Maturity of 'Deveci' Pear Cultivar. - Fruit Science (1 Special Edition): 105-111.

[27] Tatari, M., Jafari, A., Shirmardi, M., Mohamadi, M. (2019): Using morphological and physiological traits to evaluate drought tolerance of pear populations (Pyrus spp.). International Journal of Fruit Science 20(4): 837-854.

DOI: 10.1080/15538362.2019.1697410.

[28] Tozzi, F., Van Hoojdonk, B. M., Tustin, D. S., Grappadelli, L. C., Morandi, B., Losciale, P., Manfirini, L. (2018): Photosynthetic performance and vegetative growth in a new read leaf paer: comparison of using a complex, grafted-plant system. - Frontiers in Plant Science 9: 1-14.

[29] U.S. Salinity Laboratory Staff (1954): Diagnosis and Improvement of Saline and Alkalin Soils. - Agricultural Hanbook No. 60., California, USA.

[30] Zarafshar, M., Akbarina, M., Askari, H., Hosseini, S. M., Rahaie, M., Struve, D., Striker, G. G. (2014): Morphological, physiological and biochemical responses to soil water deficit in seedlings of three populations of wild pear tree (Pyrus boisseriana). Biotechnology, Agronomy, Society and Environment 18(3): 353-366. 